\title{
Differential responses of boobies and other seabirds in the Galápagos to the 1986-87 El Niño- Southern Oscillation event
}

\author{
David J. Anderson \\ Department of Biology, University of Pennsylvania, Philadelphia, Pennsylvania 19104, USA
}

\begin{abstract}
The impact of the 1986-87 El Niño-Southern Oscillation (ENSO) event on seabirds in the Galápagos Islands was generally less severe than that of the previous ENSO in 1982-83. Sea surface temperatures (SST) rose to levels comparable to those of 4 ENSOs prior to the 1982-83 event. SST became anomalous approximately in January and had returned to typical levels by July. Blue-footed booby Sula nebouxii reproductive attempts failed throughout the archipelago, and breeding colonies were deserted, shortly after SST became unusually warm in January. Masked boobies S. dactylatra, redfooted boobies $S$. sula and several other species were apparently unaffected by the anomalous conditions, or temporarily suspended breeding for several months. A gradient in both SST and in the ENSO's impact on some seabirds was evident, with populations nesting in the cooler south of the archipelago affected less than those in the warmer north. At one colony studied both before and during the ENSO, blue-footed booby failure was associated with apparent reductions in both availability and body size of their primary prey item
\end{abstract}

\section{INTRODUCTION}

Oceanographic change has a dramatic impact upon tropical seabird reproduction and adult mortality on both local and regional scales. While emphasis on the local scale predominated (Ashmole 1963, 1971, Nelson 1970,1977 . Harris 1977) prior to the 1982-83 El NiñoSouthern Oscillation (ENSO) event, the global effects of that event on seabirds prompted a reassessment of the role of regional processes. During late 1982 and the first half of 1983 , seabirds over a wide area reared few or no young and deserted their colonies (Duffy et al. 1984, Schreiber \& Schreiber 1984, papers in Robinson \& del Pino 1985, Ainley et al. in press, La Cock 1986, Norton 1986, Hatch 1987). The initial response of most central and eastern Pacific seabirds to ENSO conditions was dramatic: breeding was suspended and nesting areas were deserted (Schreiber \& Schreiber 1983, Duffy \& Merlen 1986, Gibbs et al. 1987, Vallé et al. 1987). These species' subsequent recovery was more heterogeneous. The range of variation is represented by crested terns Sterna bergii on Christmas Island that were apparently unaffected (Schreiber \& Schreiber 1986), and Galápagos penguins Spheniscus mendiculus in the western Galápagos Islands that experienced $77 \%$ adult mortality and did not resume normal breeding until
1985 (Valle 1986). The diversity of responses produced seabird assemblages with proportions and reproductive performances that were markedly different, over the short term at least, from pre-ENSO assemblages, and prompted speculation that these stochastic, regional events may rival deterministic inter- and intra-specific interactions in determining population levels (Schreiber \& Schreiber 1987; see also Nelson 1978, p. 863).

Another ENSO occurred in 1986-87 (Climate Diagn. Bull. No. 88/3). I report on the breeding of seabirds at 3 colonies in the Galápagos Islands during this event, and review meteorological and breeding data collected since 1965 to evaluate the impact of ENSO events prior to 1983 on Galápagos seabirds.

\section{MATERIALS AND METHODS}

I visited 3 colonies on the eastern fringe of the Galápagos Islands in 1987: Punta Cevallos on Isla Española (6 to 28 February), Punta Pitt on I. San Cristobal (1 to 12 March), and Darwin Bay on I. Genovesa (21 to $31 \mathrm{March}$ ) (Fig. 1). I noted the breeding status of red-footed boobies Sula sula, blue-footed boobies $S$. nebouxii, and masked boobies $S$, dactylatra, and any other seabirds present. Data from other sites in the 


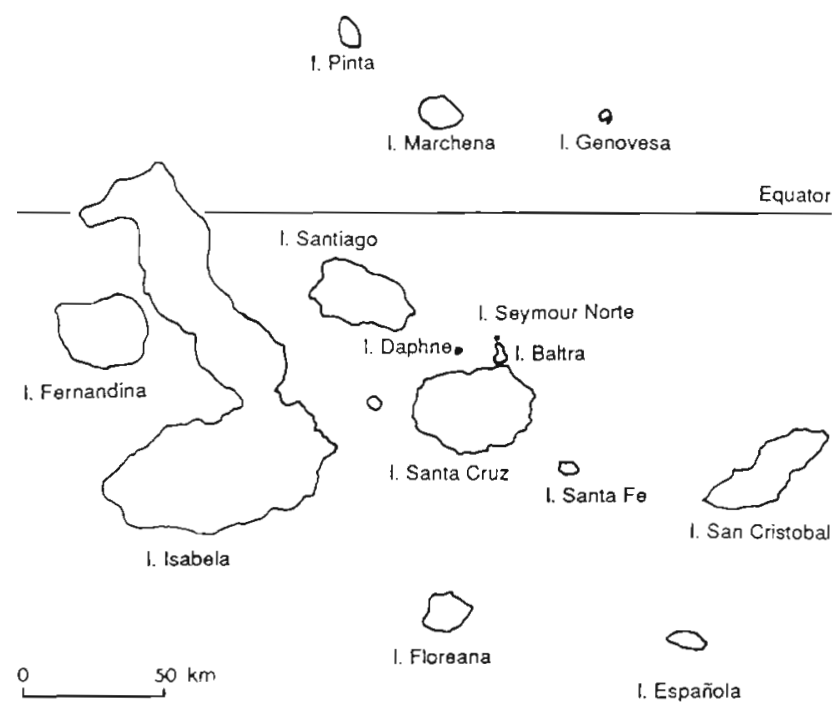

Fig. 1. Galápagos Islands, showing locations of islands mentioned in text

archipelago came from other field workers. Sea surface temperature (SST) between islands was measured with an Omega digital thermometer or with a standard mercury water temperature thermometer at $30 \mathrm{~cm}$ depth.

Excited boobies readily regurgitated their stomach contents, permitting collection of data on diet composition and standard lengths of prey of breeding adults by capturing birds immediately after their return to the colony from foraging trips. These data were collected from masked and blue-footed boobies from Punta Cevallos in both 1986 and 1987

Weather data for earlier years from the records of the Charles Darwin Research Station were analysed to summarize SST, rainfall, and breeding success of boobies. Meteorological data have been collected since 1965 at 07:00 h each day at the Station, at sea level on the southeast coast of I. Santa Cruz, roughly in the center of the archipelago. SST was measured at $30 \mathrm{~cm}$ depth from the Station pier.

Temperature anomalies were calculated on a monthly basis by subtracting the mean SST for a particular month from the grand mean for that month across years since January 1965, and were standardized across months by dividing each difference by the standard deviation of the monthly grand mean. Statistical procedures followed Sokal \& Rohlf (1981).

\section{RESULTS}

\section{Meteorological data}

Unusually high SST and rainfall are among the most obvious physical effects of ENSO in Galápagos and throughout the eastern and central Pacific (Philander 1983). The low primary productivity associated with high SST (Cowles et al. 1977, Feldman et al. 1984, Feldman 1986) is thought to reduce seabird food abundance (Murphy 1936, Nelson 1978, Barber \& Chavez 1983, Schreiber \& Schreiber 1986), and heavy rain may disrupt nesting (Schreiber \& Schreiber 1984, Rechten 1985). Both SST and rainfall cycle annually through high values in the 'warm' season and low values in the 'cool' season (Harris 1982). Figs, 2 and 3

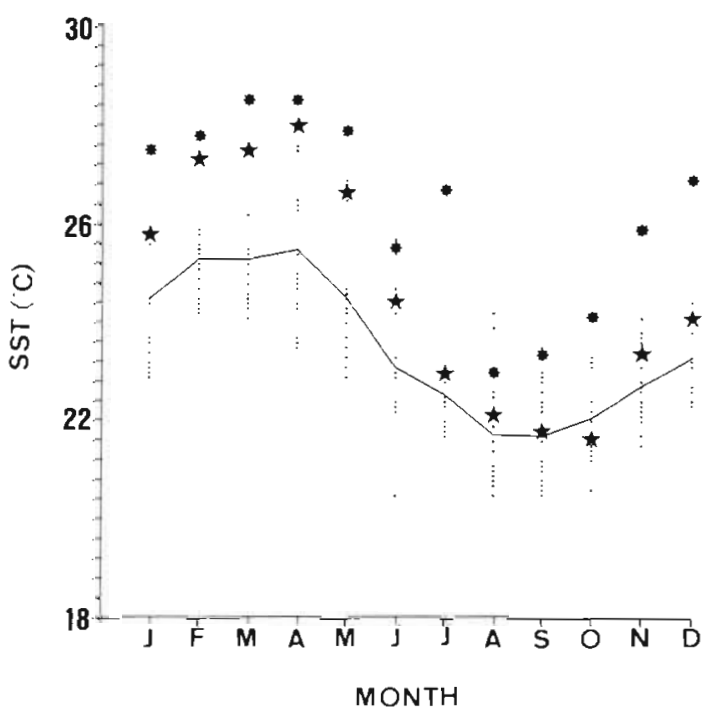

Fig. 2. Annual cycle of SST at Puerto Ayora, Isla Santa Cruz Individual points represent a mean monthly SST between January 1965 and July 1987, and the line connects grand monthly means. (*) Monthly means for the period August 1982 to July 1983; ( $\star$ ) for August 1986 to July 1987

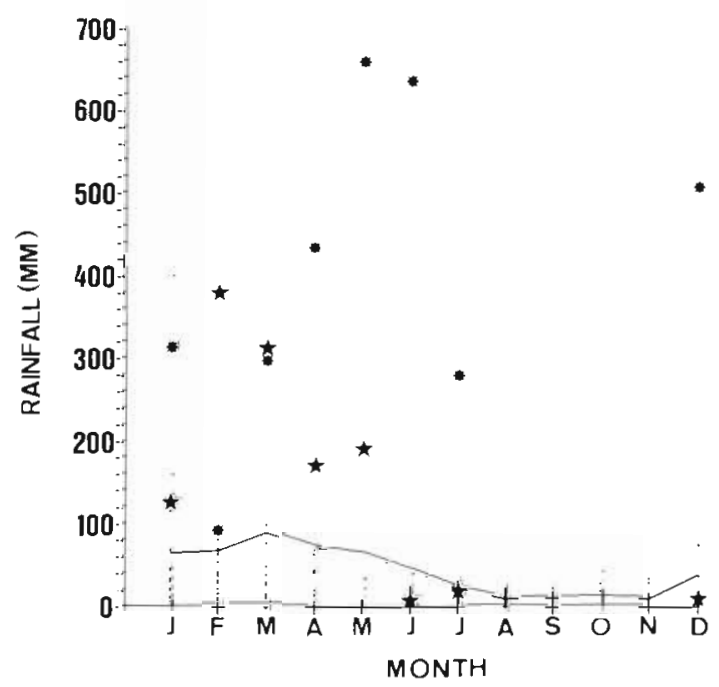

Fig. 3. Annual cycle of rainfall at Puerto Ayora, Isla Santa Cruz. Individual points represent total precipitation for a month between January 1965 and July 1987, and the line connects grand monthly means. (*) Monthly means for the period December 1982 to July 1983; ( $\star$ ) for August 1986 to July 1987 
show the distributions and means of these variables on a monthly basis. The intensity of the conditions in 1986-87 was second only to the 1982-83 ENSO event (Grant 1984) in terms of SST, and was among the wettest warm seasons since 1965 (Figs. 2 and 3). Partial rainfall records are also available from 3 other sea level sites. All are correlated with the Darwin Station set: I. San Christobal (Puerto Bacquerezo Moreno), Spearman rank correlation coefficient $r_{\mathrm{s}}=0.688, n=84, p<$ 0.01; I. Baltra (airport), $r_{\mathrm{S}}=0.346, n=78, p<0.05$; and I. Isabela (Villamil), $r_{\mathrm{S}}=0.698, n=116, p<0.01$. Thus the Darwin Station records probably reflect changes throughout the archipelago. Water temperatures were elevated throughout the eastern archipelago, as well as at Puerto Ayora. The lowest SST measured in March was $27.1^{\circ} \mathrm{C} 6 \mathrm{~km}$ southeast of I. Santa Cruz and the highest was $30.6^{\circ} \mathrm{C} 10 \mathrm{~km}$ east of I. Santa Fe. SST between I. Santa Cruz and I. Genovesa differed from that farther south between I. Santa Cruz, I. San Cristobal, and I. Española in late March. SST was generally 27.1 to $27.8^{\circ} \mathrm{C}$ to the south and 28.0 to $28.5^{\circ} \mathrm{C}$ to the north of I. Santa Cruz during this period.

\section{Responses of seabirds}

The effect of the 1986-87 ENSO on resident seabirds was less severe for some species than was that of its predecessor, and varied among species and sites. Bluefooted boobies, which normally nest at some 34 sites throughout the archipelago (Nelson 1978), were the most seriously affected. In non-ENSO years breeding is aseasonal and fairly continuous in larger colonies such as those on I. Daphne, I. Española, Punta Vicente Roca (I. Isabela), I. Seymour Norte, and Cabo Douglas (I. Fernandina). During January and February, 1987 all nestlings at these 5 sites died (pers. comms. from $M$. Ortuño, T. Orllinger, G. Keys, D. McCullough, and pers. obs.), and breeding was suspended at least until early April at these sites and at the smaller colonies at Punta Pitt and Punta Cormorant (I. Floreana) (F. Cruz pers. comm.). Adults deserted the Daphne, Punta Vicente Roca, Cabo Douglas, and Punta Cormorant colonies. The cause of nestling mortality was starvation, but at least in the case of I. Española it is not clear that this mortality resulted solely from food limitation on the part of parents. Unusually large numbers of non-breeding adults and immatures congregated to roost on coastal rock outcrops in the area of failed breeding on I. Española each night in February, apparently having foraged in the vicinity during the day. The heavy rainfall provided breeding sites for mosquitos Aedes taeniorhynchus, hundreds of which swarmed around the few blue-booted booby chicks alive in February, and which appeared to make adults reluctant to enter or remain in the inland nesting areas. Mosquito ectoparasitism has been blamed for mass desertions by waved albatrosses Diomedea irrorata at the same site in previous years (Peterson 1967, Anderson \& Fortner 1988).

Wedge-rumped storm petrels Oceanodroma tethys also abandoned their large breeding colony on I. Genovesa. On 31 March less than 15 individuals were seen flying above the colony. Eggs are laid in May and June at this colony, and in non-ENSO years the colony typically comprises many tens of thousands of birds during March (Harris 1969a, pers, obs.).

Breeding of other seabird species was affected to a lesser degree or not at all. In some species breeding characteristics varied among islands in association with the north-south SST gradient. On I. Genovesa, the most northerly island visited, masked boobies lay mainly between September and November and are feeding large nestlings in March of non-ENSO years (Nelson 1978). In 1986, before the sea became unusually warm (Fig. 2), masked boobies stopped laying eggs sometime before November but did not abandon the colony. In late March, 1987 less than $1 \%$ of the 400 pairs present had a nestling; most had recently laid eggs (10\%) or were actively courting (89\%). Swallow-tailed gulls Creagrus furcatus on I. Genovesa abandoned eggs and nestlings in early January, 1987, (A. Heise pers. comm.) as the sea became warm, and adults were present but not breeding in March 1987.

Colonies of these 2 species to the south of I. Genovesa were apparently less affected. At Punta Pitt, I. San Cristobal (Fig. 1), ca 100 non-breeding adult swallowtailed gulls and 10 recently fledged young (from clutches produced in November or December 1986) roosted in cliff nesting sites in early March. No visible nest sites contained eggs or nestlings, but inaccessible sites could not be checked and may have contained young. The masked booby colony of ca 100 pairs contained 5 nestlings. All were 70 to 80 d old (as judged by plumage) and so came from clutches laid in early December 1986, when masked boobies were not breeding on I. Genovesa, $132 \mathrm{~km}$ NNW of Punta Pitt.

Masked booby nestlings of the same age were abundant in February 1987 at the large colony at Punta Cevallos, I. Española, $186 \mathrm{~km}$ south of I. Genovesa. Colony size (ca 3500 pairs) was similar to those of the 3 previous years (pers. obs.) and little starvation mortality occurred. During 1983-85 this population laid synchronously in the last 2 mo of each year. In late 1986, however, laying was similarly synchronous but advanced by 1 mo, so that most chicks were near fledging during February. These healthy nestlings contrasted markedly with the starving chicks and corpses in the adjacent blue-footed booby colony. Swallowtailed gulls nesting among the masked boobies also 
bred during the height of ENSO conditions, and were unusually synchronous. Approximately 20 nestling gulls, but over 1000 eggs, were counted in late February 1987. Mosquito ectoparasitism on masked boobies and swallow-tailed gulls at Punta Cevallos was less obvious than on blue-footed boobies at this site, perhaps because these 2 nested on the windy shoreline, while blue-footed booby nests were in nearby, but still, inland areas.

Red-footed boobies Sula sula and great frigatebirds Fregata minor appeared unaffected by ENSO conditions. Breeding phenologies of these species on I. Genovesa were typical of non-ENSO years, with egglaying between February and April for red-footed boobies (Nelson 1978) and March and May for great frigatebirds (Harris 1982, Hernandez \& de Vries 1985). Thus, most pairs of these 2 species were initiating breeding at the same time as the sympatric masked booby pairs. Most red-footed booby pairs (84\%) were actively courting or incubating an egg in late March, but $16 \%$ of pairs had a nestling that hatched during the ENSO conditions of the previous 3 mo. Great frigatebirds had initiated breeding, and males occupied nest sites and were displaying to females, but few nests $(<10 \%)$ contained an egg. Populations of these 2 species at Punta Pitt were actively breeding, and both had eggs and chicks of all ages in early March. Red-billed tropicbirds Phaethon aethereus were found at all stages of breeding on I. Española in February and I. Daphne in April (M. Decker pers. comm.).

Breeding data are tabulated by island for the I. Genovesa (northern edge of archipelago), I. Española (southern edge), and I. San Cristobal (intermediate latitude) colonies in Table 1.

Accounts of seabird breeding activity kept since 1974 by field workers that have visited colonies show that blue-footed boobies experience massive reproductive failures much more frequently (9/152 reports) than do masked (0/64 reports) and red-footed (0/44 reports) boobies. Large-scale failures by the latter 2 species have been reported only during the unusual 1982-83 ENSO. Even during the 1976 ENSO, masked boobies on I. Daphne were incubating eggs in January, had

Table 1. Breeding activity of seabirds in early 1987 at 3 sites in the north-south SST gradient. N: no eggs or nestlings; E: eggs; SC: small chicks ( $<50 \%$ of fledging weight); LC: large chicks ( $>50 \%$ of fledging weight); F: fledglings. Data for typical years based on Harris (1969b), supplemented by pers. obs. (") and Nelson (1978) (")

\begin{tabular}{|c|c|c|c|c|}
\hline Site and species & $\begin{array}{l}\text { Typical breeding } \\
\text { status }\end{array}$ & $\begin{array}{l}1986-87 \text { ENSO } \\
\text { breeding status }\end{array}$ & $\begin{array}{c}\text { Adults typically } \\
\text { present? }\end{array}$ & $\begin{array}{l}\text { Adults present } \\
\text { in } 1987 ?\end{array}$ \\
\hline \multicolumn{5}{|l|}{ I. Genovesa } \\
\hline Masked booby & LC & $E$ & $\mathrm{Y}$ & $\mathrm{Y}$ \\
\hline \multicolumn{5}{|l|}{ Sula dactylatra } \\
\hline Red-footed booby & $\mathrm{E}, \mathrm{SC}, \mathrm{IC}, \cdots$ & $E, S C$, few, LC & Y & $\mathrm{Y}$ \\
\hline \multicolumn{5}{|l|}{ Sula sula } \\
\hline Great frigatebird & E, few SC & $E$ & Y & Y \\
\hline \multicolumn{5}{|l|}{ Fregata minor } \\
\hline Swallow-tailed gull & $\mathrm{E}, \mathrm{SC}, \mathrm{LC}^{\cdot}$ & $N$ & Y & $\mathrm{Y}$ \\
\hline \multicolumn{5}{|l|}{ Creagus furcatus } \\
\hline $\begin{array}{l}\text { Wedge-rumped storm petrel } \\
\text { Oceanodroma tethys }\end{array}$ & few $E$ & $?$ & Y & $Y($ few $)$ \\
\hline \multicolumn{5}{|l|}{ I. San Cristobal (Punta Pitt) } \\
\hline Masked booby & SC, LC & few LC & $\mathrm{Y}$ & $\mathrm{Y}$ \\
\hline Sula dactylatra & & $\mathrm{E}, \mathrm{SC}, \mathrm{LC}$ & & \\
\hline Red-footed booby & $\mathrm{E}, \mathrm{SC}(?)$ & few LC & $\mathrm{Y}$ & $\mathrm{Y}$ \\
\hline Sula sula & & $\mathrm{E}, \mathrm{SC}, \mathrm{IC}$ & & \\
\hline Blue-footed booby & ? & $\mathrm{LC}(\xi), \mathrm{F}$ & $?$ & $\mathrm{Y}($ few $)$ \\
\hline \multicolumn{5}{|l|}{ Sula nebouxii } \\
\hline Great frigatebird & $E$ & & Y & Y \\
\hline \multicolumn{5}{|l|}{ Fregata minor } \\
\hline \multicolumn{4}{|l|}{ Creagus furcatus } & $\mathrm{Y}$ \\
\hline \multicolumn{5}{|l|}{ I. Española (Punta Cevallos) } \\
\hline Masked booby & E, SC, few LC & few, SC, LC & $\mathrm{Y}^{*}$ & $\mathrm{Y}$ \\
\hline \multicolumn{5}{|l|}{ Sula dactylatra } \\
\hline Blue-footed booby & $E, S C, L C^{*}$ & few LC, dying & $Y^{*}$ & $Y(m a n y)$ \\
\hline \multicolumn{5}{|l|}{ Sula nebouxi.i } \\
\hline Swallow-tailed gull & E, SC, LC* & $\mathrm{E}, \mathrm{SC}$ & $\mathrm{Y}^{\bullet}$ & $\mathrm{Y}$ \\
\hline Creagus furcatus & & & & \\
\hline
\end{tabular}


small and large chicks in March, were apparently not breeding in late April, and had large chicks in December. Red-footed boobies on I. Genovesa had both eggs and chicks in December 1985 and September 1976. Blue-footed boobies failed mainly, but not exclusively, during extreme warm and cool periods (Fig. 4); Duffy \& Rudolf (1986) have also documented disastrous effects of cool water on seabirds.

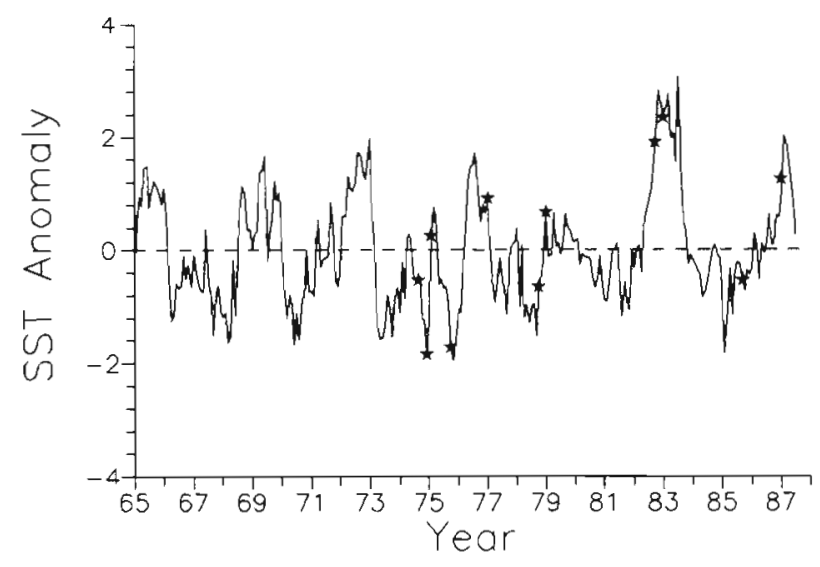

Fig. 4. SST anomaly at Puerto Ayora, Isla Santa Cruz, from January 1965 to July 1987 . See text for the method of calculating anomalies. ( ) Months in which one or more mass reproductive failures were reported for blue-footed boobies

\section{Food supply}

During both 1986 and 1987 blue-footed booby adults from Punta Cevallos preyed almost exclusively on the sardine (Clupeidae) Sardinops sagax, while masked boobies at the same site ate primarily $S$. sagax and several flying fish (Exocoetidae) species (Table 2). If changes in food supply caused the breeding failure of blue-footed but not masked boobies, this change should be reflected more strongly in S. sagax, than in exocoetid,
Table 2. Sula spp. Percentages of major prey items regurgitated by breeding boobies at Punta Cevallos in 2 years

\begin{tabular}{|rccc|}
\hline & Clupeidae & Exocoetidae & $n$ \\
\hline S. dactylatra & & & \\
1986 & 68 & 26 & 204 \\
1987 & 32 & 54 & 361 \\
S. nebouxii & & & \\
1986 & 94 & 0 & 197 \\
1987 & 98 & 0 & 54 \\
\hline
\end{tabular}

availability. In 1987, representation of $S$. sagax in the masked booby diet was $47 \%$ of that in 1986 , a statistically significant reduction $\left(G_{a d j}=68.44, p \ll 0.01\right)$. Exocoetids replaced most of this deficit (Table 2). $S$. sagax taken by both booby species were significantly smaller during the ENSO than before (Table 3; year effect in Table 4). Additionally, $S$. sagax populations preyed upon by blue-footed boobies differed to a greater degree than did those preyed upon by masked boobies (Table 3 ; year $\times$ booby interaction in Table 4 ); Anderson \& Ricklefs (1987) provided evidence of segregated foraging in these species in 1986 also. Lengths of exocoetids taken by male masked boobies did not differ in the 2 years (Wilcoxon $t_{\mathrm{s}}=1.50, p>0.10$ ) (Table 3 ), but those taken by females were smaller (Wilcoxon $t_{\mathrm{s}}=$ $1.504, p<0.05)$ in 1987. S. sagax prey lengths were reduced by as much as $27 \%$ (female blue-footed boobies). These results suggest that ENSO conditions adversely affected $S$. sagax more than exocoetid populations, and that this difference may account for the different breeding responses of Punta Cevallos boobies.

\section{Adult survival}

No evidence of unusual adult mortality (large numbers of carcasses) of any seabird was reported during

Table 3. Sula spp. Lengths of clupeid and exocoetid prey items in 1986 and 1987, grouped by year and booby species. Data are presented as mean standard lengths (in $\mathrm{mm}$ ), (SD), and sample size

\begin{tabular}{|c|c|c|c|c|}
\hline & \multicolumn{2}{|c|}{ Clupeidae } & \multicolumn{2}{|c|}{ Exocoetide } \\
\hline & Males & Females & Males & Females \\
\hline \multicolumn{5}{|l|}{1986} \\
\hline \multirow[t]{2}{*}{ S. dactylatra } & $161.9(23.1)$ & $167.3(18.4)$ & $134.3(61.1)$ & $156.3(20.9)$ \\
\hline & 48 & 58 & 28 & 16 \\
\hline \multirow[t]{2}{*}{ S. nebouxui } & $177.2(18.7)$ & $169.0(21.2)$ & - & - \\
\hline & 29 & 77 & & \\
\hline \multicolumn{5}{|l|}{1987} \\
\hline \multirow[t]{2}{*}{ S. dactylatra } & $148.8(27.1)$ & $159.0(22.2)$ & $140.8(27.9)$ & $141.9(21.8)$ \\
\hline & 32 & 57 & 69 & 100 \\
\hline S. nebouxii & $\begin{array}{c}160.8(30.4) \\
6\end{array}$ & $\begin{array}{c}124.2(21.0) \\
46\end{array}$ & - & - \\
\hline
\end{tabular}


Table 4. Analysis of variance of clupeid prey items from Table 3 . Variances of cells are homogeneous $\left[F_{\max ; 8.5}=2.73, p>0.05\right]$

\begin{tabular}{lrrrrr}
\hline Source & Sum of squares & DF & Mean square & F-ratio \\
\hline Year & 21146.2 & 1 & 21146.2 & 44.63 & $p$ \\
Booby & 98.8 & 1 & 98.8 & 0.21 & $<0.001$ \\
Sex & 2618.7 & 1 & 2618.7 & 5.53 & 0.648 \\
Year $\times$ Booby & 4902.5 & 1 & 4902.5 & 10.35 & 0.019 \\
Year $\times$ Sex & 1717.9 & 1 & 1717.9 & 3.63 & 0.001 \\
Booby $\times$ Sex & 11358.8 & 1 & 11358.8 & 23.97 & $<0.001$ \\
Year $\times$ Booby $\times$ Sex & 3417.5 & 1 & 3417.5 & 7.21 & 0.008 \\
Error & 163464.4 & 345 & 473.8 & & \\
\hline
\end{tabular}

the 1986-87 ENSO, in accord with descriptions of most species during the 1982-83 ENSO (Duffy \& Merlen 1986, Vallé et al. 1987).

\section{DISCUSSION}

The impact of the 1986-87 ENSO on most Galápagos seabirds was mild relative to that of the unusually intense 1982-83 event (Vallé et al. 1987), and the 1986-87 event seemed to be more similar to the 1976 event, at least for boobies, than to the 1982-83 event. Thus, the 1986-87 ENSO may be more typical meteorologically and in terms of seabird breeding success of ENSO in Galápagos than was the severe 1982-83 event. If so, then the ecological and evolutionary role of ENSO events in seabird biology may have been overestimated for some species following studies during the unusual 1982-83 ENSO.

While brown pelicans Pelecanus occidentalis, Galápagos penguins, and flightless cormorants Nannopterum harrisi nesting in the upwelling area west of I. Isabela have been vulnerable to these typical ENSOs in the past (Boersma 1976, 1978, Harris 1979), only blue-footed boobies among the seabirds nesting east of I. Isabela are known to have failed on the same scale as during the 1982-83 event (Fig. 4; see also Nelson 1978 , p. 540). This sensitivity may depend as much on the blue-footed booby's ability to begin breeding quickly when conditions normalize as on reproductive difficulties during the ENSO. Blue-footed boobies in Galápagos are opportunistic, rather than seasonal, breeders (Nelson 1978, p. 539) and can initiate a clutch when adverse conditions pass rather than wait for a particular point in the annual cycle, as many Galápagos seabirds do (Harris 1982). Thus, there is less risk for an aseasonal breeder in deserting offspring with an uncertain future than for a seasonal breeder.

It is interesting to note that of the 17 seabird species for which clutch size data are available (Harris 1982), only these 4 species mentioned above (plus the lava gull Larus fuliginosus for which few breeding data are available) have clutch sizes larger than one egg (considering the obligately siblicidal masked booby to be effectively a single-chick species (Nelson 1978)). In species with broods larger than one, sibling competition may select for faster growth rates (Werschkul \& Jackson 1979, but see Ricklefs 1982, Bortolotti 1986) and a closer relationship between food intake and chick fitness, than in species with a single chick. The impact of a given degree of food limitation would thus be greater per chick for multi-chick species than for single-chick species. The sibling competition hypothesis predicts that multi-chick species would thus be expected to experience both higher chick mortality and selection on parents favoring earlier desertion of broods with questionable futures than would singlechick species, a pattern consistent with that observed in Galápagos seabirds.

The annual cycle of SST in Galápagos results from interactions between warm water masses north of the Equatorial (or Galapagos) Front, cool water masses to the south, and upwelling of the Equatorial Undercurrent (Pak \& Zaneveld 1974, Houvenaghel 1978). To the east of I. Isabela, the warm/cool gradient shifts along this north-to-south axis seasonally with year-to-year variation in the progress of a particular isotherm up and down the gradient (Houvenaghel 1978). ENSO conditions are extreme variants of the annual cycle, and a weak gradient was maintained in 1982-83 (Hayes $1985)$ as well as in 1987. Although the non-ENSO shifting of this gradient past I. Genovesa does not have any known proximate effect on seabirds breeding there, masked boobies and swallow-tailed gulls showed stronger effects at the northern than at the southern end of the axis during the 1986-87 ENSO; body condition of marine iguanas Amblyrhynchus cristatus was also higher in the south than in the north during this ENSO (T. Dellinger pers. comm.). Such a north-to-south gradient in response may shed some light on the mysterious absence of the more sensitive blue-footed booby from islands north of the equator (Harris 1982). SST of 27.0 to $28.0^{\circ} \mathrm{C}$ throughout the 
waters east of I. Isabela in 1987 was associated with blue-footed booby reproductive failure throughout the region. Data from the Darwin Station (Fig. 2) and Houvenaghel (1978, Fig. 3a) suggest that the maximum southern extension of the $27.0^{\circ}$ isotherm during nonENSO years is an imaginary line extending approximately from northern I. San Cristobal to northern I. Isabela. The northern islands above this line are the only islands in the archipelago avoided by blue-footed boobies. The reason may be that these islands are all surrounded by water warmer than $27.0^{\circ} \mathrm{C}$ during the warm season, conditions that, during 1987, were unsuitable for blue-footed booby reproduction. The mechanistic factors restricting blue-footed boobies to cooler water are unknown, but a role for Sardinops sagax distributions seems likely. The incursion of warm water into the area around Punta Cevallos was associated with changes in the primary prey of blue-footed boobies, but the interactions between water temperature and fish populations remain unstudied elsewhere in the archipelago, as do the trophic links between water temperature and fish populations.

In contrast to the blue-footed booby distribution, masked booby colonies world-wide are located primarily in warmer waters (Nelson 1978, p. 869). The I. Española population's highly seasonal and synchronous laying is unusual and perhaps unique for this species, and is radically different in this respect even from the I. Genovesa population $186 \mathrm{~km}$ to the north (Nelson 1978, p. 373). The early laying at this colony in late 1986 (relative to laying dates in the previous 3 years), in association with rapidly rising SST in October and November (Fig. 2), suggests that this species closely tracks the cyclical shifting of the SST gradient [or some other correlated factor(s)]. An explanation at the proximate level for this tracking is that breeding becomes possible when SST (or some factor correlated with SST) reaches a threshold level, but the different responses of the I. Española and I. Genovesa populations are also consistent with Schreiber \& Schreiber's $(1985,1987)$ implication that this species is able to recognize signs of impending poor conditions and to respond appropriately. During the period when SST was rapidly rising but was still months from reaching its peak, I. Española masked boobies advanced their laying dates and bred successfully, while I. Genovesa birds (at the warmer, north end of the SST gradient) stopped breeding altogether. Our inability to separate effects at the proximate and ultimate levels highlights our poor understanding of the environmental factors controlling seabird reproduction. Until this central problem can be addressed, we must rely on only moderately informative correlations with broad ecological variables like SST to understand seabird reproductive dynamics.
Acknowledgements. Field work in Galápagos since 1984 has been supported by the National Geographic Society, the George D. Harris Foundation, the Chapman Fund, a University of Michigan Block Grant, and Sigma Xi. The Charles Darwin Research Station, Galápagos National Park Service, Ecuadorian Navy, and the captain and crew of the 'Kanowie' provided logistical support in 1987 Permission to work in the Galápagos National Park was granted by the Dirección General de Desarrollo Forestal, Quito. I am grateful to $M$. Arguello, C. Carroll, M. Decker, P. Niewiarowski, S. Serrano, and $\mathrm{L}$. Willimont for field assistance, and to S. Harcourt for facilitating many aspects of this work. G. Davis and $M$. Robalino helped me locate meteorological data. J. Pecor identified mosquito specimens, and B. Chernof and J. Grove identified fish specimens. D. Anderson, D. Boersma, M. Coulter, R. Ricklefs, and R. Schreiber made helpful comments on the manuscript. This is publication No. 435 of the Charles Darwin Research Station

\section{LITERATURE CITED}

Ainley, D. G., Carter, H. R., Anderson, D. W., Briggs, K. T., Coulter, M. C., Cruz, F., Cruz, J. B., Merlen, G., Vallé, C., Fefer, S. I., Hatch, S. A., Schreiber, E. A., Schreiber, R. W., Smith, N. G. (in press). 'El Niño'-Southern Oscillation 1982-83 and effects on Pacific Ocean marine bird populations. Proc. Int. Ornithol, Congr. Ottawa

Anderson, D. J., Fortner, S. (1988). Waved albatross egg neglect and associated mosquito ectoparasitism. Condor 90: $727-729$

Anderson, D. J., Ricklefs, R. E. (1987). Radio-tracking masked and blue-footed boobies (Sula spp.) in the Galápagos Islands. National Geographic Research 3: 152-163

Ashmole, N. P. (1963). The regulation of numbers of tropical oceanic birds. Ibis 103b: 458-473

Ashmole, N. P. (1971). Sea bird ecology and the marine environment. In: Farner, S., King, J. R. (eds.) Avian biology, Vol. 1. Academic Press, New York, p. 223-286

Barber, R. T., Chavez, F. P. (1983). Biological consequences of El Niño. Science 222: 1203-1210

Boersma, P. D. (1976). An ecological and behavioral study of the Galápagos penguin. Living Bird 15: 43-93

Boersma, P. D. (1978). Breeding patterns of Galápagos penguins as an indicator of oceanographic conditions. Science 200: $1481-1483$

Bortolotti, G. R. (1986). Evolution of growth rates in eagles: sibling competition vs. energy considerations. Ecology 67 : 182-194

Climate Diagnostics Bulletin No. 88/3. Climate Analysis Center, National Oceanic and Atmospheric Administration, Washington, D.C

Cowles, T., Barber, R, Guillen, O. (1977). Biological consequences of the 1975 El Niño. Science 195: 285-287

Duffy, D. C. (1984). Nest site selection by masked and bluefooted boobies on Isla Española, Galápagos. Condor 86: 301-304

Duffy, D. C., Berruti, A., Randall, R. M., Cooper, J. (1984). Effects of the 1982-83 warm water event on the breeding of South African seabirds. S. Afr. J. Sci. 80: 65-69

Duffy, D. C., Merlen, G. (1986). Seabird densities and aggregations during the 1983 El Niño in the Galápagos Islands. Wilson Bull. 98: 588-591

Duffy, D. C., Rudolf, A. (1986). Cape cormorant mass mortality during a cold-water event off Namibia. Ostrich 57: $247-248$ 
Feldman, G. C. (1986). Variability of the productive habitat in the eastern equatorial Pacific. Eos 67: 106-108

Feldman, G., Clark, D., Halpern, D. (1984). Satellite color observations of the phytoplankton distribution in the eastern equatorial Pacific during the 1982-1983 El Niño. Science 226: 1069-1070

Gibbs, H. L. Latta, S. C., Gibbs, J. P. (1987). Effects of the 1982-83 El Niño event on blue-footed and masked booby populations on Isla Daphne Major, Galápagos. Condor 89 . $440-442$

Grant, P. R. (1984). Extraordinary rainfall during the El Nino event of 1982-83. Not. Galápagos 39: 10-12

Harris, M. P. (1969a). The biology of storm petrels in the Galápagos Islands. Proc. Calif. Acad. Sci. 37: 95-166

Harris, M. P. (1969b). Breeding seasons of sea-birds in the Galápagos Islands. J. Zool., Lond. 159: 146-165

Harris, M. P. (1977). Comparative ecology of seabirds in the Galápagos archipelago. In: Stonehouse, B., Perrins, C. (eds.) Evolutionary ecology. Macmillan Press, New York, p. 65-76

Harris, M. P. (1979). Population dynamics of the flightless cormorant Nannopterum harrisi. Ibis 121: 1135-146

I Iarris, M. P. (1982). A field guide to the birds of Calápagos. Collins, London

Hatch, S. A. (1987). Did the 1982-1983 El Nino-Southern Oscillation affect seabirds in Alaska? Wilson Bull. 99: $468-474$

Hayes, S. P. (1985). Sea level and near surface temperature variability at the Galápagos Islands, 1979-83. In: Robinson, G., del Pino, E. M. (eds.) El Niño in the Galápagos Islands: the 1982-1983 event. Charles Darwin Foundation for the Galápagos Islands, Quito, p. 49-82

Hernandez, C., de Vries, Tj. (1985). Fluctuaciones en la población de fragatas Fregata minor en la Bahia Darwin, Genovesa durante 1975-1983. In: Robinson, G., del Pino, E. M. (eds.) El Niño in the Galápagos Islands: the 1982-1983 event. Charles Darwin Foundation for the Galápagos Islands, Quito, p. 239-244

Houvenaghel, G. T (1978). Oceanographic conditions in the Galápagos archipelago and their relationships with life on the islands. In: Boje, R., Tomczak, M. (eds.) Upwelling ecosystems. Springer-Verlag, Berlin, p. 181-200

La Cock, G. D. (1986). The Southern Oscillation, environmental anomalies, and mortality of two southern African seabirds. Climatic Change 8: 173-184

Murphy, R. C. (1936). Oceanic birds of South America. Macmillan Press. New York

Nelson, J. B. (1970). The relationship between behavior and ecology in the Sulidae with reference to other seabirds. Oceanogr mar Biol. A. Rev. 8: 501-574

Nelson, J. B. (1977). Some relationships between food and breeding in the marine Pelecaniformes. In: Stonehouse, B.,

This article was submitted to the editor
Perrins, C. (eds.) Evolutionary ecology. Macmillan Press New York, p. 77-87

Nelson, J. B. $\{1978\}$. The Sulidae. Oxford University Press, Oxford

Norton, R. L. (1986). Climatic influences on seabird populations of the tropical. western Atlantic. Pac. Seab. Grp Bull. 13: 44

Pak, H., Zaneveld, J. R. V (1974). Equatorial front in the eastern Pacific Ocean. J. phys. Oceanogr. 4: 570-578

Philander, S. G. H. (1983). El Nirio Southern Oscillation phenomena. Nature, Lond. 302: 295-301

Peterson, R. T. (1967). The Galápagos. National Geographic Magazine 131. 541-585

Rechten, C. (1985). The waved albatross in 1983 El Nino leads to complete failure. In: Robinson, G., del Pino, E. M. (eds.) El Niño in the Galápagos Islands: the 1982-1983 event. Charles Darwin Foundation for the Galápagos Islands Quito, p. 227-237

Ricklefs, R. E. (1982). Some considerations on sibling competition and avian growth rates. Auk 99: 141-147

Robinson, G., del Pino, E. M. (1.985). El Nino in the Galápagos Islands: the 19821983 cvont Charles Darwin Foundation for the Galápagos Islands, Quito

Schreiber, R. W., Schreiber, E. A. (1983). Reproductive failure of marine birds on Christmas Island, Fall 1982. Trop. Ocean-Atmos. Newsl 16: 10-12

Schreiber, R. W., Schreiber, E. A. (1984). Central Pacific seabirds and the El Niño Southern Oscillation: 1982 to 1983 perspectives. Science 225: 713-716

Schreiber, R. W., Schreiber, E. A. (1985), The role of central Pacific seabirds in predicting the 1982-83 ENSO. World Meteorological Organization, World Climate Research programme, Publications Series No. 4: 32-37

Schreiber, R. W., Schreiber, E. A. (1986). Christmas Island (Pacific Ocean) seabirds and the El Niño Southern Oscillation (ENSO): 1984 perspectives. In: NATO ASI Series, Vol G 12 Mediter Mar. Avifauna. Springer-Verlag, Berlin, p $397-408$

Schreiber, R. W., Schreiber, E. A. (1987). Equatorial seabirds and El Niño: close encounters in a marine ecosystem. Trop Ocean-Atmos. Newsl 37: 14-15

Sokal, R. R., Rohlf, F. J. (1981). Biometry. San Francisco, W. H Freeman

Werschkul, D F., Jackson, J. A. (1979). Sibling competition and avian growth rates. Ibis 121:97-102

Vallé, C. (1986). Status of the Galápagos penguin and flightless cormorant populations in 1985. Not. Galápagos 43: 16-17

Vallé, C. A., Cruz, F., Cruz, J. B., Merlen, G., Coulter, M. C. (1987). The impact of the 1982-83 El Niño-Southern Oscillation on seabirds in the Galápagos Islands, Ecuador. J geophys. Res 92: 14437-14444

Manuscript received: September 16, 1988

Revised version accepted: December 30, 1988 